\title{
SCIENTIFIC CIVIL SERVICE
}

\section{PROMOTION OF INDIVIDUAL RESEARCH WORKERS}

$S^{P}$ PECIAL posts have again been created this year in the Scientific Civil Service under provisions included in the White Paper (Cmd. 6679; 1945) designed to provide for the promotion of individual research workers of exceptional merit. The promotions are effective from July 1 .

\section{Deputy Chief Scientific Officers}

Dr. S. G. BAUER has worked in the British Atomic Energy project since its earliest war-time days. $\mathrm{He}$ was a member of the British team in Canada, and returned to Great Britain when the Harwell establishment was opened. His work has been mainly devoted to the development of nuclear power reactors, and he has made great advances in the technology of the special materials and processes which such reactors require.

DR. S. J. Folley, who since 1945 has been head of the Physiology Department of the National Institute for Research in Dairying, Reading, joined the staff of the Institute in 1932 and has since then been working on various physiological aspects of lactation and reproduction. Much of his research has been on the endocrinology of these related activities, on mammary growth and on the biosynthesis of milk fat, and he has made substantial contributions to knowledge in each of these three fields. He was a Rockefeller Foundation Fellow in 1938, studying at Yale University. $\mathrm{He}$ is at present chairman of the Society for Endocrinology. He was elected a Fellow of the Royal Society in 1951.

Dr. P. Fortescue worked before and during the Second World War with the Bristol Aeroplane Co., Ltd., on gas turbine development, making notable advances in axial and centrifugal compressors and in automatic control systems. At the Atomic Energy Research Establishment, Harwell, he is in charge of the Engineering Laboratory, working primarily on heat-transfer problems connected with nuclear reactors, and on the development of special pumps and compressors.

Dr. G. G. MacFartant joined the Telecommunications Research Establishment of the Ministry of Supply in 1939 after carrying out research on theoretical problems in electrical engineering at the Technische Hochschule, Dresden, as Matthew Gray Scholar of the University of Glasgow. $\mathrm{He}_{\Theta}$ has done important fundamental work in quantum mechanics and electromagnetic theory. $\mathrm{He}_{\theta}$ has also been prominent in the investigation of theoretical problems arising in the development of radar equipment and has made valuable contributions in this field.

\section{Senior Principal Scientific Officers}

Mr. G. E. BACON joined the Atomic Energy Research Establishment, Harwell, in 1946, after wartime service in the Telecommunications Research Establishment on the development of ground radar equipment, particularly aerial systems. At Harwell he has worked on the application of X-ray and neutron diffraction techniques to the study of the solid state. An important part of this work has been research on the structure of graphite and investigations of single-crystal methods of neutron diffraction analysis.

DR. E. H. Bateman's varied experience included structural engineering, educational work in the R.A.F. and lecturing in civil engineering at the University of Birmingham before he joined the Ministry of Home Security in 1939 to work on camouflage. In 1944 he transferred to the Armament Design Establishment, Ministry of Supply, and in 1952 to the Royal Aircraft Establishment. While at the former Establishment he not only carried out much valuable design work but also made special investigations into the analysis of mechanisms. In addition, he produced his well-known second-order iterative solution for solving algebraic and transcendental equations and for the inverse interpolation of functions, together with his development of matrix solutions for vibration problems involving structural discontinuities and for statistical problems which are beyond the practicable range of existing methods. At the Royal Aircraft Establishment he has done valuable work on thermal stresses caused by kinetic heating of high-speed aircraft and guided weapons.

Mr. J. B. Bratr joined the National Physical Laboratory, Teddington, in 1937, where he has carried out valuable work in the measurement of aerodynamic forces on oscillating aerofoils for both subsonic and supersonic flow. His applications of electrical methods to the technique of measurement are outstanding. They have been of very great value both in providing experimental checks on results given by theory, and in exploring difficult problems where theory is uncertain-for example, those concerned with nearly or completely stalled flow, effects of Reynolds number, influence of compressibility especially in the transonic region, and effects of aerofoil thickness. The information obtained from such work is vital for the prediction of the behaviour of modern high-speed aircraft.

Mr. R. Donatdson joined the National Physical Laboratory, Teddington, in 1928 after two years as demonstrator in the Physics Department of the University of Edinburgh. He has been primarily occupied with the theoretical development of the quantitative evaluation of light, covering the whole field of colorimetry, heterochromatic photometry and spectrophotometry, and has made notable contributions to all these branches of the subject by the design of instruments and the development of techniques to meet the ever-widening requirements of industry. His name first became prominent in this field with the development of his trichromatic colorimeter, which he described in 1935 and which is now the most widely used trichromatic colorimeter in the English-speaking countries. His most recent work is concerned with the re-determination of the constants of the C.I.E. system of colour measurement and with problems of fluorescence. 
Dr. S. Neumark had considerable experience before the Second World War as a lecturer and research worker in aerodynamics and applied mathematics in Warsaw, at the Technical University, the Aerodynamic Institute, and the Institute of Aeronautical Research. During 1937-39 he was professor of mechanics in the Polish Air Force College, Warsaw, and while in the Polish Air Force he joined the Royal Aircraft Establishment, Ministry of Supply, remaining there on demobilization. He has done distinguished work in theoretical aerodynamics, especially investigations into problems of stability and control and in fluid motion, including theoretical flow over sweptback wings, and he is widely known for his researches in these fields.

Dr. W. G. S. Parker entered the Royal Aircraft Establishment, Ministry of Supply, in 1936. He worked initially on a wide variety of physicochemical problems in the aircraft field and made many valuable contributions. Since 1946 he has been concerned with the difficult problems of the mechanism of burning and decomposition of oxidizing fuels and propellants, and his work in this sphere has earned him an international reputation. In particular his research on carbon formation and on the structure of diffusion flames has advanced considerably the understanding of combustion in air flames and has had important applications in the study of fire prevention.

DR. S. M. PARTRIdGe, for two years prior to joining the D.S.I.R., held a Beit Memorial Fellowship for Medical Research, working at the Lister Institute for Preventive Medicine. He joined the D.S.I.R. in 1942 to assist a team at the Low Temperature Research Station, Cambridge, studying dehydrated meat, and was responsible for the development on the pilot-plant scale of a process for its manufacture. Since the Second World War, in the course of his investigations on connective tissues (cartilage, elastic tissues, etc.), he has made notable contributions to analytical methods in biochemistry. He was a pioneer in the application of partition chromatography on filter paper to the analysis of sugars and in the development of displacement chromatography of organic compounds using ion-exchange resins. His contributions to biochemistry are finding numerous applications, not only to foods but also to medical research and other fields of applied biochemistry.

Mr. E. O. Powell was with the Chemical Defence Experimental Establishment, Ministry of Supply, during 1941-46, and after a short period on industrial research re-joined the Ministry of Supply in the Microbiological Research Department in 1947. His versatility and insight have enabled him to make valuable contributions in such diverse fields as bacteriology, chemistry, mathematics and physics. $\mathrm{He}$ has done particularly important work in the development of micro-manipulative techniques for the study of individual bacterial cells, and also in bacterial genetics.

Mr. G. D. Robinson joined the Meteorological Office in 1936. He has made valuable detailed studies in atmospheric radiation and in the transfer of heat, momentum and water vapour between the ground and the air, and his published papers on this work are widely recognized as important contributions. These investigations of basic problems of energy exchange in the atmosphere are to be extended.

\section{WORLD FEDERATION OF SCIENTIFIC WORKERS}

\section{ASSEMBLY AT BUDAPEST}

$T$ HE World Federation of Scientific Workers held its third assembly during September $12-14$ in Budapest, at the invitation of the Hungarian Association of Scientists and Engineers. Thirty-five representatives of organizations of scientists in Bulgaria, Canada, China, Czechoslovakia, Denmark, France, Great Britain, Hungary, India, Poland and the U.S.S.R. attended the sessions. The proceedings were opened by the president, Prof. Frederic JoliotCurie. The president's speech emphasized the need for scientists to inform the public of the useful things which science can provide, and to try to promote international exchanges of scientific literature and of personal visits as a contribution to improving international relations. Apart from organizational matters, the Assembly discussed certain questions of general interest to scientists. Reports on the salaries and conditions of work of scientists in various countries represented at the Assembly were presented. Special attention was devoted to the difficulties which are at present being experienced in connexion with exchanges of scientific books and periodicals. It is greatly to be hoped that an improvement in these exchanges can be achieved by the concerted action of all scientists in all countries. It was also decided to extend the publications of the Federation with the view of giving a presentation of the positive and constructive way in which science could contribute to the welfare of all peoples if it were freed from many of its present restrictions.

'The resolutions passed by the Assembly made the following points: $(a)$ that scientific workers everywhere should strive to secure the peaceful solutions of all international differences, so that less attention will be given to military preparations and more to the peaceful uses of science; $(b)$ that governments could and should, by international negotiations, reach agreement regarding the prohibition of weapons of mass destruction; and (c) that academic freedom should be preserved and that the restrictions to which scientists are subjected should be reduced.

Laboratories and museums of all kinds were visited by delegates to the Assembly, and Hungarian scientists showed great pleasure in discussing scientific matters with their guests. To judge from the laboratories which have been recently completed and from those which are now in the process of building, it may be said that scientific institutions are rapidly developing and that large funds are available for this purpose. Many university teachers and research workers are engaged in writing text-books in the Hungarian language. The number of students in universities and institutes of higher education has increased seventeen-fold since 1939. During the same period the number of technical universities has increased from one to five, and the number of scientific books published each year by a factor of ten. Parallel with this great internal growth in education and research, there has developed a need for better contact with foreign science.

A novel feature of this Assembly was the holding of lectures on scientific subjects, given to the various Hungarian scientific societies, and they evoked great interest and discussion. Among the lecturers were: Prof. E. Aubel (France), on the mechanism and role of the biological reduction of nitrates; Prof. J. D. 